\title{
Self-Efficacy as a Predictor of Life Satisfaction among Undergraduate Students
}

\author{
Masaud Ansari, 1 , Dr. Kr. Sajid Ali Khan 2
}

\section{ABSTRACT:}

In the present investigation an attempt was made to study the Self-efficacy, as a predictor of Life satisfaction among undergraduate students. A sample of 120 under-graduate students from Faculty of Social Science, AMU, Aligarh was drawn by using purposive sampling technique. General Self-Efficacy Scale-Hindi Version (GSE-H) developed by Jerusalem \& Schwarzer (1992) and Satisfaction with life Scale developed by Diener, Emmons, Larsen, and Griffen (1985) were administered. For the data analyses Simple Linear Regression was applied. The findings of the present study showed that Self-efficacy and Life Satisfaction significantly correlated with each other and Self-Efficacy had its significant impact on Life Satisfaction among under-graduate students.

Keywords: Self-Efficacy, Life Satisfaction and Under-Graduate Students.

\section{INTRODUCTION}

\section{Rational or background of the study}

Self-efficacy considered as the ability to persist and a potential of person to succeed with a task and it affects every area of human endeavor. The undergraduate students are concern; they are at the crucial stage where they have to face several challenges related to their education and professional life as well. So, researcher considers this group of the population more important for the study of their life satisfaction, in terms of Self-efficacy as compare to other age group of the individuals.

\section{Self-efficacy}

Self-efficacy is the extent or strength of one's belief in one's own ability to complete tasks and reach goals Ormrod (2006). Self-efficacy affects every area of human endeavor. By determining the beliefs a person holds regarding his or her power to affect situations, it strongly influences both the power a person actually has to face challenges competently and the choices a person is most likely to make. These effects are particularly apparent, and compelling, with regard to behaviors affecting health (Luszczynska and Schwarzer, 2005). Self-efficacy is typically defined as a judgment of one's ability to organize and execute a particular type of performance (cf.e.g. Bandura, 1986, 1997). More specifically, it is a belief about whether one can produce certain actions. In other words, self-efficacy is exercising control over one's life (Bandura, 1986, 1997).

${ }^{1}$ Research Scholar, Department of Psychology, Aligarh Muslim University, Aligarh.

${ }^{2}$ Associate Professor, Department of Psychology, Aligarh Muslim University, Aligarh.

(C) 2015, M Ansari, S Khan; licensee IJIP. This is an Open Access Research distributed under the terms of the Creative Commons Attribution License (http://creativecommons.org/licenses/by/2.0), which permits unrestricted use, distribution, and reproduction in any Medium, provided the original work is properly cited. 


\section{Life satisfaction}

Life satisfaction is the way a person evaluates his or her life and how he or she feels about where it is going in the future. It is a measure of well-being and may be assessed in terms of mood, satisfaction with relations with others and with achieved goals, self-concepts, and self-perceived ability to cope with daily life. It is having a favorable attitude of one's life as a whole rather than an assessment of current feelings*.

Life satisfaction can reflect experiences that have influenced a person in a positive way. These experiences have the ability to motivate people to pursue and reach their goals (Bailey et al., 2007).

\section{REVIEW OF LITERATURE}

High efficacy beliefs are also related to the expansion of satisfying social relations that bring about life satisfaction to an individual (Bandura, 1997). Therefore, social quality of life and satisfaction with accomplishments should be high in self-efficacious individuals. Life satisfaction has been directly related to self-efficacy. Hampton's (2000) study of 100 Chinese individuals with spinal cord injuries found that self-efficacy was related to both the quality of life and the life satisfaction of the patients tested. Hampton (2000) found that "self efficacy and health status were significantly correlated with life satisfaction"' (p. 69). Furthermore, "the major contributor to life satisfaction was self-efficacy, which had the highest partial correlation with life satisfaction after health status and demographic variables were controlled', (p. 70).

People generally avoid tasks where self-efficacy is low, but undertake tasks where self-efficacy is high. When self-efficacy is significantly beyond actual ability, it leads to an overestimation of the ability to complete tasks. On the other hand, when self-efficacy is significantly lower than actual ability, it discourages growth and skill development. Research shows that the optimum level of self-efficacy is slightly above ability; in this situation, people are most encouraged to tackle challenging tasks and gain experience (Csikszentmihalyi, 1997). The Self-efficacy, affects every area of human endeavor. By determining the beliefs a person holds regarding his or her power to affect situations, it strongly influences both the power a person actually has to face challenges competently and the choices a person is most likely to make. These effects are particularly apparent, and compelling, with regard to behaviors affecting health (Luszczynska \& Schwarzer, 2005).

One of the most studied concepts of personality is big five model with dimensions of openness to experience, conscientiousness, extraversion, agreeableness, and neuroticism. In a research carried out by Deneve and Cooper in 1998, multiple studies were analyzed and certain personality questionnaires that linked subjective well-being (SWB) and personality measures. They found that neuroticism was the strongest predictor of life satisfaction and negative affect while the personality measure 'openness to experience' correlated equally to life satisfaction and positive affect. Amongst other personality traits chronotype has been consequently related to life 
satisfaction; morning oriented people (larks) showed higher life satisfaction than evening oriented individuals (owls). Where individuals are having a general self-efficacy belief they have some principal features in the way that the feeling of the ability to cope with difficulties. Certain stability in reactions towards stressful situations has been reached and a certain continuity of the feeling of this self-efficacy belief has been provided (Schwarzer, 1994; Schwarzer \& Jerusalem, 1995).

Life satisfaction can reflect experiences that have influenced a person in a positive way. These experiences have the ability to motivate people to pursue and reach their goals. There are two emotions that may influence how people perceive their lives. Hope and optimism both consist of cognitive processes that are usually oriented towards the reaching of goals and the perception of those goals. Additionally, optimism is linked to higher life satisfaction whereas pessimism is related to symptoms in depression. According to Seligman (2002), the more happy people are, the less they are focused on the negative. They also tend to like others more, which creates an overall happiness which then correlates to a higher level of satisfaction with their life. Academic, social and self-regulatory self-efficacy beliefs seem to be particularly relevant for adolescents' life satisfaction, due to the influence that academic success, social competence and avoidance of risky behavior may exert in fostering desirable and satisfactory courses of life (Roeser et al., 1999 and Rubin et al., 2006).

Researchers was examined the predictive power of self-efficacy beliefs, the predictive power of academic achievement and peer acceptance. Indeed, both academic success and peer preference have been shown to be determinants of youth' $s$ satisfaction (Cheng and Furnham, 2002 and Kirkcaldy et al., 2004). While academic success is related to a more satisfying academic and professional career (Bandura, 1997 and Pajares, 2006).

\section{OBJECTIVES:}

- To see the relationship between Self-Efficacy and Life Satisfaction among undergraduate students.

- To examine the impact of Self-efficacy on life satisfaction among under-graduate students.

\section{RESEARCH QUESTIONS:}

- Is there any relationship between Self-Efficacy and Life Satisfaction among undergraduate students?

- Is there any impact of Self-efficacy on life satisfaction among under-graduate students? 


\section{METHOD}

\section{Sample}

The sample of the study consisted of 120 Under-Graduate students (age range 18-22), selected from Faculty of Social Science, Aligarh Muslim University, Aligarh. A purposive sampling technique was used to select the participants of the study.

\section{Tools}

\section{General Self-Efficacy Scale-Hindi Version (GSE-H)}

General Self-Efficacy (GSE) scale was developed by Jerusalem and Schwarzer. He first developed originally the German version of this scale as 20 -items and later he translated this scale into German to English and reduced 10-items (Jerusalem \& Schwarzer, 1992). After a short period of time Sud (2002) also translated this scale from English to Hindi version. Therefore, general self-efficacy scale (Hindi version) consists of 10 -items rated on four point rating scale with the response categories i.e. (1) not at all true, (2) hardly true, (3) moderately true, and (4) exactly true. For scoring, all the ten items are added to yield the final composite score with a range from 10-40. The reliability coefficient of the scale was found to be ranging between 0.76 to 0.90 .

\section{Satisfaction with Life Scale (SWLS)}

The SWLS, which was developed by Diener, Emmons, Larsen, and Griffen (1985), contains five global items that were developed to assess an individual's satisfaction with life as a whole. The scale uses a 7point Likert-type format that is as follows: strongly disagree (1), disagree (2), slightly disagree (3), neither agree nor disagree (4), slightly agree (5), agree (6), and strongly agree (7). The scores range from 5 to 35 , the higher scores indicating more satisfaction with life. Hence, in terms of total scores, 5 to 9 indicates extremely dissatisfied with life, 10 to 14 indicates dissatisfied with life, 15 to 19 indicates slightly dissatisfied with life, 20 represents equally satisfied and dissatisfied with life, 21 to 25 indicates slightly satisfied, and 26 to 30 indicates satisfied with life, and 31 to 35 indicates extremely satisfied with life. Test-retest reliability and Cronbach's alpha were reported 0.82 and 0.87 , respectively.

\section{Procedure}

The scales were administered on the Under-Graduate students individually, before distributing the respective tools good rapport was established and proper instructions were given to the participants and also ensured for confidentiality; after that questionnaires were given, participants were taken 10-20 minutes to give their complete responses on the measures and then the data were collected.

\section{Statistical Analysis}

In order to meet the research objectives Simple Linear Regression was applied. 


\section{RESULTS AND DISCUSSION}

The following contents represent the results of the study as well as discussion of the research findings.

Table-1: Represents Simple Linear Regression analysis, Self-efficacy as predictor of Life satisfaction among Under-Graduate Students.

\begin{tabular}{|l|r|r|r|r|}
\hline \multicolumn{5}{|c|}{ Model Summary } \\
\hline Model & $\mathrm{R}$ & $\mathrm{R}$ Square & $\begin{array}{c}\text { Adjusted R } \\
\text { Square }\end{array}$ & $\begin{array}{c}\text { Std. Error of the } \\
\text { Estimate }\end{array}$ \\
\hline 1 & $.743^{\mathrm{a}}$ & .552 & .548 & 4.163 \\
\hline \multicolumn{5}{|l}{} \\
a. Predictors: (Constant), Self-Efficacy
\end{tabular}

Table-1 represents the model summary indicating one predictor of the model, in which correlation between self-efficacy and life satisfaction was found to be $\mathrm{R}=.743$ and $\mathrm{R}$ Square $=.552$ which represents the actual contribution of self-efficacy to life satisfaction, the real covariance magnitude of predictor variable which contribute to criterion variable find out $55.2 \%$.

Table-2: Showing the Coefficient details of Self-efficacy and Life satisfaction of Under-Graduate Students.

\begin{tabular}{|c|c|c|c|c|c|c|}
\hline \multicolumn{7}{|c|}{ Coefficients $^{\mathrm{a}}$} \\
\hline \multirow{2}{*}{\multicolumn{2}{|c|}{ Model }} & \multicolumn{2}{|c|}{ Unstandardized Coefficients } & \multirow{2}{*}{$\begin{array}{c}\begin{array}{c}\text { Standardized } \\
\text { Coefficients }\end{array} \\
\text { Beta } \\
\end{array}$} & \multirow[b]{2}{*}{$\mathrm{t}$} & \multirow[b]{2}{*}{ Sig. } \\
\hline & & B & Std. Error & & & \\
\hline \multirow[t]{2}{*}{1} & (Constant) & -6.957 & 2.600 & & -2.676 & .009 \\
\hline & Self-Efficacy & .984 & .082 & .743 & 12.063 & .000 \\
\hline
\end{tabular}

Table-2 indicates that self-efficacy significantly influence to the life satisfaction. The statistical value given in the above table indicate that $\mathrm{t}=12.063$ which is significant for the predictor variable.

The value of standardized coefficient (Beta) is .743 which indicates the degree of correlation between self-efficacy and life satisfaction. The relationship between these two variables represents linear correlation; it means that when self-efficacy increases life satisfaction also increases and when selfefficacy decreases life satisfaction decreases.

The first finding of the study showed that self-efficacy and life satisfaction significantly correlated with each other. A research conducted by Hampton (2000) reveals that Life satisfaction has been directly related to self-efficacy. Hampton's study of 100 Chinese individuals with spinal cord injuries found that self-efficacy was related to both the quality of life and the life satisfaction of the patients tested. He found that "self efficacy and health status were significantly correlated with life satisfaction". Furthermore, "the major contributor to life satisfaction was self-efficacy, which had the highest partial correlation with life satisfaction after health status and demographic variables were controlled". 
The second finding of the study indicates the significant impact of self-efficacy on life satisfaction. It is also reported by Bandura (1997), he found that High efficacy beliefs are also related to the expansion of satisfying social relations that bring about life satisfaction to an individual. Therefore, social quality of life and satisfaction with accomplishments expected to be high in self efficacious individuals. An individual who has high self-efficacy can deal with more challenging situations as compare to those who has poor self-efficacy. According to Seligman (2002), the more happy people less focused on the negative. They also tend to like others more, which creates an overall happiness which then correlates to a higher level of satisfaction with their life.

\section{CONCLUSION}

Consequently, it is concluded that self-efficacy has its major impact on life satisfaction where Life satisfaction can reflect experiences that have influenced a person in a positive way. These experiences have the ability to motivate people to pursue and reach their respective goals. It is found that, People generally avoid tasks where they perceive the self-efficacy is low, but undertake tasks where self-efficacy is high. When self-efficacy is significantly beyond actual ability, it leads towards an overestimation of the ability to complete tasks. It means that for the satisfaction with life self-efficacy must be enhance either as a student, academician or professional.

\section{ACKNOWLEDGEMENTS}

I wish to pay heartfelt thanks to Dr. Kr Sajid Ali Khan, Associate Professor, Department of Psychology, Aligarh Muslim University, Aligarh for his constant guidance. I express my thanks to all participants in the study, my colleagues and friends who help me in this part of research.

\section{REFERENCES}

1. A Review of Life Satisfaction Research with Children and Adolescents, p. 196. Retrieved 5 March (2013)*.

2. Bailey, T., Eng, W., Frisch, M. \& Snyder, C. R. (2007). "Hope and optimism as related to life satisfaction." Journal of Positive Psychology, 2(3), 168-69.

3. Bandura (1997). A. Bandura Self-efficacy: The exercise of control Freeman, New York (1997).

4. Bandura, A. (1986). Self-efficacy In Bandura, A. (Ed.), Social foundations of thoughts and action: A social cognitive theory (pp. 390-453). Englewood Cliffs, NJ: Prentice-Hall.

5. Bandura, A. (1997). Self-efficacy: The exercise of control. New York: W. H. Freeman.

6. Chang, E. C., \& Sanna, L. J. (2001). Optimism, pessimism, and positive and negative affectivity in middle-aged adults: a test of a cognitive-affective model of psychological adjustment. Psychology and Aging, 16(3), 524-531. doi: 10.1037/08827974163524.

7. Cheng and Furnham, (2002). H. Cheng, A. Furnham Personality, peer relations, and selfconfidence as predictors of happiness and loneliness. Journal of Adolescence, 25 (2002), pp. 327 339.

8. Csikszentmihalyi, M., Finding Flow, (1997).

9. Díaz-Morales, J.F., Jankowski, K.S., Vollmer, C., Randler, C. (2013). Morningness and life satisfaction: further evidence from Spain. Chronobiology International, 30,1283-1285.

10. Diener, E., Emmons, A., Larsen, J., \& Grrifen, S. (1985). The satisfaction with life scale. J Rur Commun Psych, 3, 27-34.

11. Eisenberg N. (2006). (Ed.), Handbook of child psychology, Social, emotional, and personality development (6th ed.), Wiley, New York, pp. 894-941 
12. Hampton, N. (2000). Self-efficacy and quality of life in people with spinal cord injuries in China. Rehabilitation Counseling Bulletin, 43, 66-74.

13. Jankowski, K.S. (2012). Morningness/Eveningness and Satisfaction With Life in a Polish Sample.Chronobiology International, 29,780-785.

14. Jerusalem, M., \& Schwarzer, R. (1992). Self-efficacy as a resource factor in stress appraisal process. In R. Schwarzer (Ed.), Self-efficacy: Thought control of action (pp 195-211). Washington, D.C.: Hemisphere.

15. Kirkcaldy et al., (2004) B. Kirkcaldy, A. Furnham, G. Siefen The relationship between health efficacy, educational attainment, and well-being among 30 nations European Psychologist, 9 (2004), pp. 107-119.

16. Life Review Therapy Using Autobiographical Retrieval Practice for Older Adults with Depressive Symptomatology, p.274. Retrieved 7 March (2013)*.

17. Life Satisfaction, OECD, Better Life Index. Retrieved 7 February (2013)*.

18. Luszczynska, A., \& Schwarzer, R. (2005). Social cognitive theory. In M. Conner \& P. Norman (Eds.), Predicting health behaviour (2nd ed. rev., pp. 127-169). Buckingham, England: Open University Press.

19. Luszczynska, A., \& Schwarzer, R. (2005). Social cognitive theory. In M. Conner \& P. Norman (Eds.), Predicting health behaviour (2nd ed. rev., pp. 127-169). Buckingham, England: Open University Press.

20. Luszczynska, A., \& Schwarzer, R. (2005). Social cognitive theory. In M. Conner \& P. Norman (Eds.), Predicting health behaviour (2nd ed. rev., pp. 127-169). Buckingham, England: Open University Press.

21. Ormrod, J. E. (2006). Educational psychology: Developing learners (5th ed.). Upper Saddle River, N.J.: Pearson/Merrill Prentice Hall.

22. Pajares, (2006). F. Pajares Self-efficacy during childhood and adolescence: Implications for teachers and parents F. Pajares, T. Urdan (Eds.), Self-efficacy beliefs of adolescents, IAP Information AgePublishing Inc. (2006), pp. 339-367

23. Roeser et al., (1999). R.W. Roeser, J.S. Eccles, C. Freedman-Doan Academic functioning and mental health in adolescence: Patterns, progressions, and routes from childhood Journal of Adolescent Research, 14 (1999), pp. 135-174

24. Rubin et al., (2006). K.H. Rubin, W. Bukowski, J. Parker Peer interactions, relationships, and groups.

25. Schwarzer, R. \& Jerusalem, M. (1995). Generalized Self-Efficacy Scale. In Weinman, J, S Wright, and M. Johnson (Ed.), Measures in health psychology: A user's portfolio, Causal and control beliefs (pp. 35-37). Windsor England: NFER-NELSON.

26. Schwarzer, R. (1994). Optimism, vulnerability, and self-beliefs as health-related cognitions: A systematic overview. Psychology and Health: An International Journal, 9, 161-180.

27. Seligman, M. (2002). "Positive emotions undo negative ones". Authentic Happiness. New York, New York: Simon \& Schuster.

28. Work-Family Conflict, Policies, and the Job-Life Satisfaction Relationship: A Review and Directions for Organizational Behavior-Human Resources Research. p. 145. Retrieved 5 March $2013 *$. 